\section{Three new fungi from Silent Valley National Park, Kerala, India}

\author{
V.B. Hosagoudar ${ }^{1} \&$ M.C. Riju ${ }^{2}$ \\ 1,2 Tropical Botanic Garden and Research Institute, Palode, \\ Thiruvananthapuram, Kerala 695562, India \\ Email: ${ }^{1}$ vbhosagoudar@rediffmail.com (corresponding author)
}

There are several sporadic reports on fungi of Silent Valley National Park, but a consolidated account of any group of fungi of this evergreen forest is lacking. We have been making continuous efforts in the study of these fungi (Hosagoudar et al. 1996; Florence 2004; Hosagoudar \& Biju 2006; Hosagoudar et al. 2010; Rajeshkumar \& Hosagoudar 2010; Shaji \& Hosagoudar 2010) and in this note we provide an account of three new fungi.

\section{Asteridiella toddaliae sp. nov.} (Fig. 1)

Material examined: 02.viii.2008, on leaves of Toddalia asiatica (L.) Lam. (Rutaceae), Cheriavalakkad, Silent Valley National Park, Palakkad, Kerala, India, coll. M.C. Riju et al. TBGT 4513 (holotype). Part of the collection has been deposited in HCIO, New Delhi, (MycoBank \# 561021).

Coloniae amphigenae, densae, velutinae, ad

Date of publication (online): 26 March 2011

Date of publication (print): 26 March 2011

ISSN 0974-7907 (online) | 0974-7893 (print)

Editor: Richard Mibey

Manuscript details:

Ms \# 02641

Received 07 December 2010

Final received 10 February 2011

Finally accepted 15 February 2011

Citation: Hosagoudar, V.B. \& M.C. Riju (2011). Three new fungi from Silent Valley National Park, Kerala, India. Journal of Threatened Taxa 3(3): 1615-1619.

Copyright: (C) V.B. Hosagoudar \& M.C. Riju 2011. Creative Commons Attribution 3.0 Unported License. JoTT allows unrestricted use of this article in any medium for non-profit purposes, reproduction and distribution by providing adequate credit to the authors and the source of publication.

Acknowledgements: We thank the director, TBGRI, Palode for providing facilities and to Mr. T. Shaju, TBGRI, Palode for identifying the host plants.

\section{OPEN ACGESS | FREE DOWNLOAD}

$3 \mathrm{~mm}$ diam., raro confluentes. Hyphae rectae, subrectae vel undulatae, plerumque opposite laxe ramosae, laxe vel arte reticulatae, cellulae 22-30 x 7-10 $\mu \mathrm{m}$. Appressoria alternata, unilateralis, ad 10\% opposita, antrorsa vel subantrorsa, raro retrorsa, $12-25 \mu \mathrm{m}$ longa; cellulae basilares cylindraceae vel cuneatae, 2-8 $\mu \mathrm{m}$ longae; cellulae apicales ovatae, globosae, integrae, 10-18 x 7-13 $\mu \mathrm{m}$. Phialides appressoriis intermixtae, alternatae, oppositae, ampulliformes, 15-23 x 5-8 $\mu \mathrm{m}$. Perithecia laxe aggregata ad coloniis centre, ad $210 \mu \mathrm{m}$ diam.; cellulae peritheciales mammiformes vel conoideae, 17-28 $\mu \mathrm{m}$ longae; ascosporae oblongae vel ellipsoideae, 4-septatae, constrictus ad septatae, 45-48 x 22-25 $\mu \mathrm{m}$.

Colonies amphigenous, dense, velvety, up to $3 \mathrm{~mm}$ diam., rarely confluent. Hyphae straight, substraight to undulating, branching mostly opposite at wide angles, loosely to closely reticulate, cells $22-30 \times 7-10 \mu \mathrm{m}$. Appressoria alternate, unilateral, about $10 \%$ opposite, antrorse to subantrorse, rarely retrorse, $12-25 \mu \mathrm{m}$ long; stalk cells cylindrical to cuneate, $2-8 \mu \mathrm{m}$ long; head cells ovate, globose, entire, $10-18 \times 7-13 \mu \mathrm{m}$. Phialides mixed with appressoria, alternate, opposite, ampulliform, $15-23 \times 5-8 \mu \mathrm{m}$. Perithecia loosely grouped at the centre of the colony, up to $210 \mu \mathrm{m}$ in diam.; perithecial wallcells mammiform to conoid, 17-28 $\mu \mathrm{m}$ long; ascospores oblong to ellipsoidal, 4-septate, constricted at the septa, $45-48 \times 22-25 \mu \mathrm{m}$.

Of the known species of the genus Asteridiella on Rutaceae, Asteridiella obesa (Speg.) Hansf. var. obesula (Speg.) Hansf. and A. fagaricola (Speg.) Hansf. var. zanthoxyli Hansf. having alternate and opposite appressoria (Hansford 1961). The present new species differs from the former taxon known on Esenbeckia latifolia from Paraguay in having perfectly rounded head cells of appressoria in contrast to rounded-angulose. It also differs from the latter taxon known on Zanthoxylum hymenale from Argentina in having only $10 \%$ opposite appressoria in contrast to 90\% (Hansford 1961). The specific epithet is derived from the host genus. 


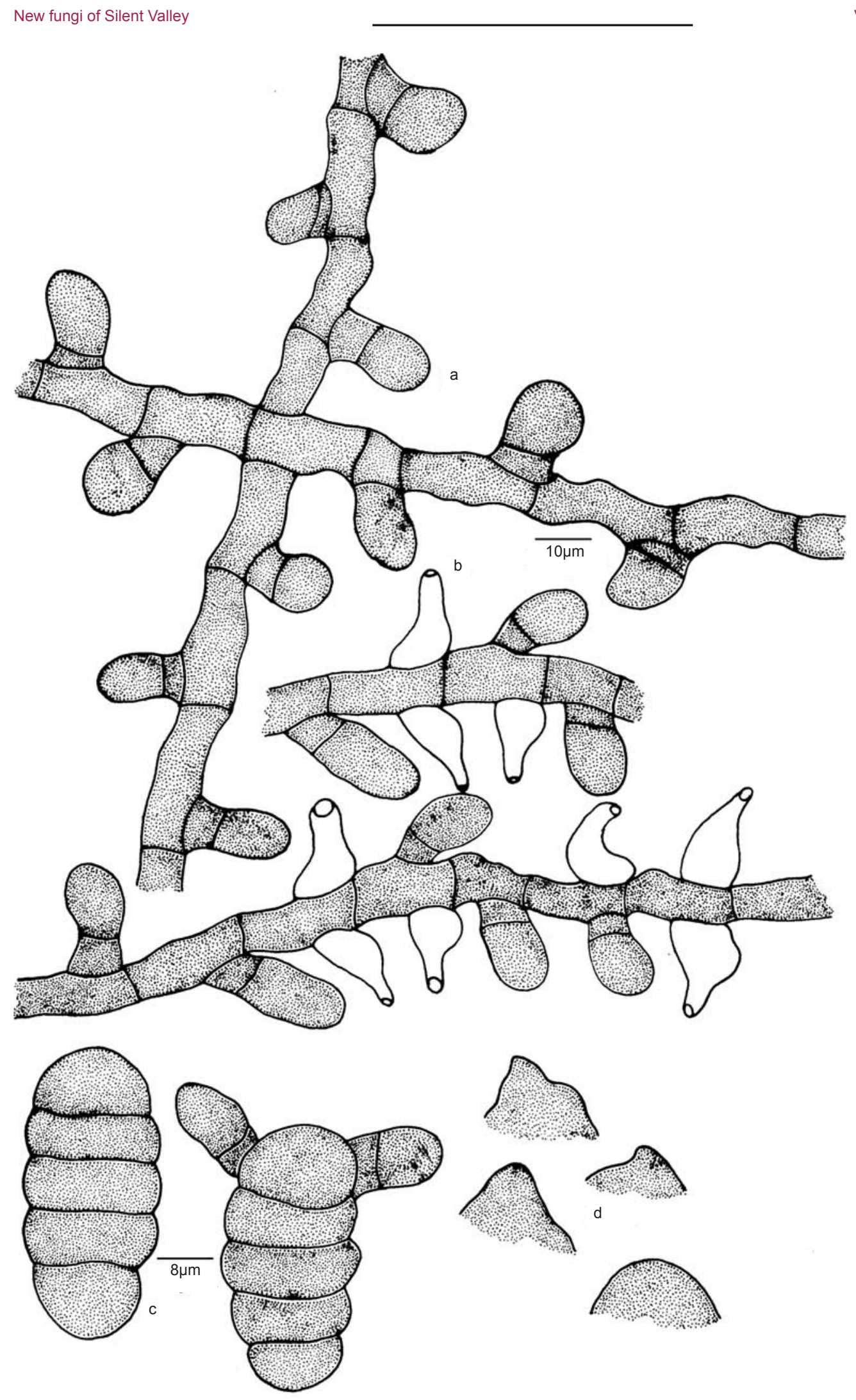

V.B. Hosagoudar \& M.C. Riju

Figure 1. Asteridiella toddaliae sp. nov.

a - Appressorium; b - Phialide; c - Ascospores; $d$ - Perithecial wall cells 


\section{Meliola clausenigena sp. nov.}

(Fig. 2)

Material examined: 01.viii.2008, on leaves of Clausena sp. (Rutaceae), Poochipara, Silent Valley National Park, Palakkad, Kerala, India, coll. M.C. Riju et al. TBGT 4514 (holotype). Part of the collection has been deposited in HCIO, New Delhi, (MycoBank \# 561022).

Coloniae amphigenae, densae, velutinae, ad 3mm diam., dispersae vel confluentes. Hyphae rectae, flexuosae, opposite laxe ramosae, laxe vel arte reticulatae, cellulae 15-30 x 5-8 $\mu \mathrm{m}$. Appressoria plerumque opposita, raro unilateralis, antrorsa vel subantrorsa, 17-23 $\mu \mathrm{m}$ longa; cellulae basilares cylindraceae vel cuneatae, 5-8 $\mu \mathrm{m}$ longae; cellulae apicales ovatae, oblongae, raro globosae, rectae vel curvulae, integrae, saepe sinuatae, truncatae ad apicem, $12-15 \times 7-10 \mu \mathrm{m}$. Phialides appressoriis inter mixtus, oppositae, alternatae vel unilateralis, $15-20 \times 7-10$

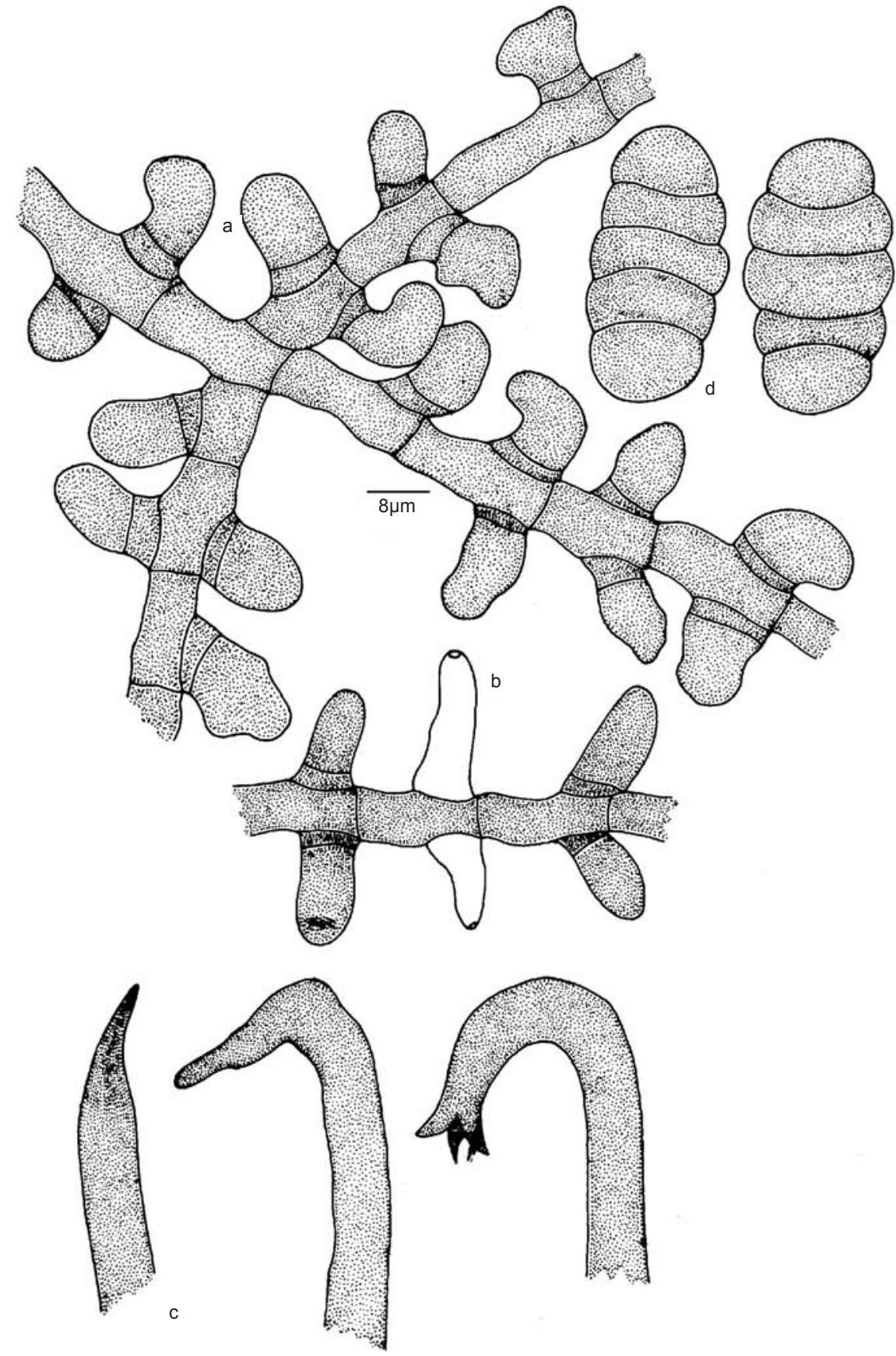

Figure 2. Meliola clausenigena sp. nov. a - Appressorium; b - Phialide; $c$ - Apical portion of the mycelial setae; $d$ - Ascospores 
$\mu \mathrm{m}$. Setae myceliales simplices, rectae vel uncinatae ad portionio apicalis, acutae, obtusae vel 2-3-dentatae ad apicem, ad $240 \mu \mathrm{m}$ longae. Perithecia dispersa vel aggregata, ad $190 \mu \mathrm{m}$ diam.; ascosporae oblongae vel cylindraceae, 4-septatae, constrictus ad septatae, 37$40 \times 15-20 \mu \mathrm{m}$.

Colonies amphigenous, dense, velvety, up to $3 \mathrm{~mm}$ in diam., scattered to confluent. Hyphae straight, flexuous, branching opposite at wide angles, loosely to closely reticulate, cells $15-30 \times 5-8 \mu \mathrm{m}$. Appressoria mostly opposite, rarely unilateral, antrorse to subantrorse, 17 $23 \mu \mathrm{m}$ long; stalk cells cylindrical to cuneate, $5-8 \mu \mathrm{m}$ long; head cells ovate, oblong, rarely globose, straight to curved, entire, often sinuate, truncate at the apex, $12-15 \times 7-10 \mu \mathrm{m}$. Phialides mixed with appressoria, opposite, alternate to unilateral, $15-20 \times 7-10 \mu \mathrm{m}$. Mycelial setae simple, straight to uncinate at the apical portion, acute, obtuse to 2-3-times dentate at the tip, up to $240 \mu \mathrm{m}$ long. Perithecia scattered to grouped in the colonies, up to $190 \mu \mathrm{m}$ in diam.; ascospores oblong to cylindrical, 4-septate, constricted at the septum, $37-40 \times 15-20 \mu \mathrm{m}$.

This is the only species of the genus Meliola known on the members of the family Rutaceae having straight, curved to uncinate apical portion of the mycelial setae (Hansford 1961; Hosagoudar et al. 1996; Hu et al. 1996, 1999; Hosagoudar 1996, 2008; Hosagoudar \& Agarwal 2008). The specific epithet is derived from the host genus.

\section{Meliola strombosiigena sp. nov.}

(Fig. 3)

Material examined: 01.viii.2008, on leaves of Strombosia sp. (Olacaceae), Cheriavalakkad, Silent Valley National Park, Palakkad, Kerala, India, coll.

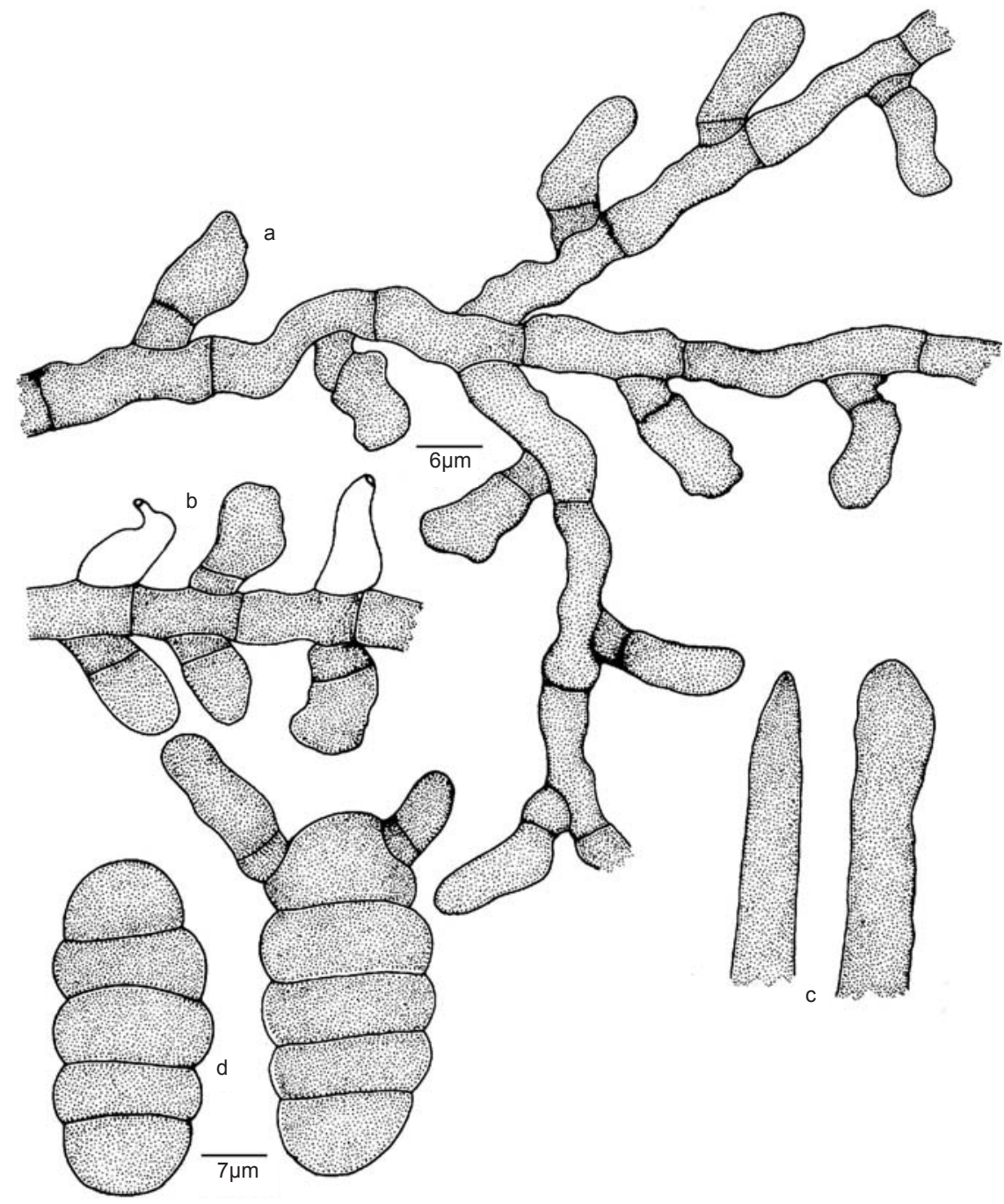

Figure 3. Meliola strombosiigena sp. nov.

a - Appressorium; b - Phialide; c - Apical portion of the mycelial setae; d-Ascospores 
M.C. Riju et al. TBGT 4515 (holotype). Part of the collection has been deposited in HCIO, New Delhi, (MycoBank \# 561023).

Coloniae amphigenae, plerumque hypophyllae, densae, velutinae, ad 4mm diam., confluentes. Hyphae flexuosae vel undulatae, opposite vel alternatim acuteque vel laxe ramosae, laxe vel arte reticulatae, cellulae $15-25 \times 5-10 \mu \mathrm{m}$. Appressoria alternata, opposita vel unilateralis, antrorsa vel subantrorsa, raro retrorsa, 17-28 $\mu \mathrm{m}$ longa; cellulae basilares cylindraceae vel cuneatae, 5-8 $\mu \mathrm{m}$ longae; cellulae apicales oblongae vel cylindraceae, rectae vel flexuosis curvulae, integrae, $10-20 \times 5-8 \mu \mathrm{m}$. Phialides appressoriis intermixtus, alternatae, oppositae vel unilateralis, ampulliformes, $20-30 \times 6-8 \mu \mathrm{m}$. Setae myceliales rectae vel curvulae, dispersae, acutae ad apicem, ad $720 \mu \mathrm{m}$ longae; Perithecia dispersa, ad $240 \mu \mathrm{m}$ diam.; ascosporae obovoideae, 4-septatae, constrictus ad septatae, 50-55 x 20-23 $\mu \mathrm{m}$.

Colonies amphigenous, mostly hypophyllous, dense, velvety, up to $4 \mathrm{~mm}$ diam., confluent. Hyphae flexuous to undulate, branching opposite to alternate at acute to wide angles, loosely to closely reticulate, cells 15-25 × 5-10 $\mu \mathrm{m}$. Appressoria alternate, opposite to unilateral, antrorse to subantrorse, rarely retrorse, 17-28 $\mu \mathrm{m}$ long; stalk cells cylindrical to cuneate, 5-8 $\mu \mathrm{m}$ long; head cells oblong to cylindrical, straight to flexuously curved, entire, $10-20 \times 5-8 \mu \mathrm{m}$. Phialides mixed with appressoria, alternate, opposite to unilateral, ampulliform, 20-30 x 6-8 $\mu \mathrm{m}$. Mycelial setae straight to curved, scattered, acute at the tip, up to $720 \mu \mathrm{m}$ long; Perithecia scattered in the colonies, up to $240 \mu \mathrm{m}$ in diam.; ascospores obovoidal, 4-septate, constricted at the septa, $50-55 \times 20-23 \mu \mathrm{m}$.

Meliola strobosiae Hosag. et al. is known on Strombosia ceylonica from Kukke Subramanya, Karnataka (Hosagoudar 2008). However, the present new species differs from it in having narrow head cells (5-8 $\mu \mathrm{m}$ against $8-12 \mu \mathrm{m})$ and larger spores $(50-55$ x 20-23 against $36-40 \times 15-17 \mu \mathrm{m})$. The specific epithet is derived from the host genus.

\section{REFERENCES}

Florence, E.J.M. (2004). Biodiversity Documentation for Kerala. Part 2: Microorganisms (Fungi). Kerala Forest Research Institute, Peechi, 293pp.

Hansford, C.G. (1961). The Meliolineae. A Monograph. Sydowia Beihefte 2: 1-806.

Hosagoudar, V.B. (1996). Meliolales of India. Botanical Survey of India, Calcutta, 363pp.

Hosagoudar, V.B. (2008). Meliolales of India. Vol. II. Botanical Survey of India, Calcutta, 390pp.

Hosagoudar, V.B., T.K. Abraham \& P. Pushpangadan (1996). Fungi of Kerala. Tropical Botanic Garden and Research Institute, Palode, Thiruvananthapuram, 151pp.

Hosagoudar, V.B. \& D.K. Agarwal (2008). Taxonomic studies of Meliolales. Identification Manual. International Book Distributors, Dehra Dun, 263pp.

Hosagoudar, V.B. \& H. Biju (2006). Studies on foliicolous fungi - XXII. Microfungi of Silent Valley National Park, Palghat district in Kerala State. Journal of Mycopathological Research 44: 39-48

Hosagoudar, V.B., M.C. Riju \& D.K. Agarwal (2010). Three new Meliolaceae members from Silent Valley National Park. Indian Phytopathology 63: 76-78.

Hu, Y., Y. Ouyang, S. Bin \& G. Jiang (1996). Flora Fungorum Sinicorum. Vol. 4. Meliolales (1). Science Press Beijing, $270 \mathrm{pp}+$ plate IV.

Hu, Y., S. Bin, Y. Ouyang \& G. Jiang (1999). Flora Fungorum Sinicorum. Vol. 11. Meliolales (2). Science Press Beijing, 252pp.

Rajeshkumar, P.P. \& V.B. Hosagoudar (2010). Occurrence of Endomycorrhizal fungi in Poochipara forests in Silent Valley National Park in Kerala state. National Seminar on Biodiversity: for Human Welfare, held in the Department of Studies and Research in Microbiology, Cauvery Campus, Madikeri, Kodagu, on $7^{\text {th }}-8^{\text {th }}$ April, 2010, 87pp.

Shaji, S.S. \& V.B. Hosagoudar (2010). Endomycorrhizal fungi in Sairandri and Neelikkallu sections of Silent Valley National Park, Kerala. National Conference on Plant Biodiversity on $23^{\text {rd }}$ and $24^{\text {th }}$ April. Dept. of Botany, Yashvantarao Chavan Institute of Science, Satara, Maharashtra, 39pp. 